\title{
The Investigation of Relative Efficacy Family Training and Life Strategies on Caring Chronic Mental Illness in Family
}

\author{
Hoseini Shadi', Toozandehjani Hassan² \\ Department of Psychology, Faculty of Humanities, Neyshabur Branch, Islamic Azad University, Neyshabur, Iran \\ Email: dy.hoseyni@gmail.com, H.Toozandehjani@ymail.com
}

How to cite this paper: Shadi, H. and Hassan, T. (2017) The Investigation of Relative Efficacy Family Training and Life Strategies on Caring Chronic Mental Illness in Family. Open Journal of Medical Psychology, 6, 133-143.

https://doi.org/10.4236/ojmp.2017.62011

Received: November 18, 2016

Accepted: April 25, 2017

Published: April 28, 2017

Copyright $\odot 2017$ by authors and Scientific Research Publishing Inc. This work is licensed under the Creative Commons Attribution International License (CC BY 4.0).

http://creativecommons.org/licenses/by/4.0/

\begin{abstract}
This research is a semi-empirical study aiming to examine the effect of family trainings and life skills among the families, if Mashhad with chronic mental disorders. In doing this research, a sample of 300 subjects has been chosen in the stratified random and systematic approach from the families of chronic mental disorders who have been admitted in round the clock centers in Mashhad and who have been in the waiting list and these subjects have been divided to two groups of experiment and control randomly and we introduce family trainings and life skills to the experiment group. There was no training to control group. These two groups were tested in period to the beginning of trainings and post training with instruments such as taking care and mental disorders attitude questionnaire, life skills attitude questionnaire, California social adjustment questionnaire, Rosenberg self-esteem, general health questionnaire and epidemiological mental disorders questionnaire. The result indicated that training had no effect on the attitude of families toward taking care of mental disorder, but family member's attitude toward mental disorder had been changed. These trainings have been influential on changing family member's attitude toward life skills, social adjustment, self-esteem, mental health increase and reducing mental disorders.
\end{abstract}

\section{Keywords}

Relative Efficacy Family Training, Life Strategies, Chronic Mental Illness

\section{Introduction}

Family is a semi-organized system which plays the role of internal communica-

${ }^{1}$ M.A. in Clinical Psychology, Department of Psychology, Faculty of Humanities, Neyshabur Branch, Islamic Azad University, Neyshabur, Iran. Email: dy.hoseyni@gmail.com

${ }^{2}$ Assistant Professor, Ph.D. of Psychology, Department of Psychology, Faculty of Humanities, Neyshabur Branch, Islamic Azad University, Neyshabur, Iran. Email: H.Toozandehjani@ymail.com 
tion and possesses members who have acquired different positions and places and perform its roles according to the content of the role, positions, thought, and kinship relationships. One of the main duties of families is providing a suitable environment for nurturing family members and supplying security and mental and physical hygiene for all the family members. Psychological and educational commentators consider family organization as the most important institution in nurturing and human behavior and consider family environment as the basic and most enduring factor in the personality genesis of human and the laying plot for their physical, moral, social, rational and affective development [1].

This belief that family members gain many of their characteristics from learning experiences in family is one of the obvious findings of today's thought. So is this belief that problematic families nurture problematic people. The main assumption is that behavioral and emotional problems are due to structural characteristics of families, so any change in undesirable structure of families which continue these problems can be effective in changing subject's symptoms [2].

The belief that social problems are related to family function and so we can (according to this function in society) correct them goes back to at least 18th century. However, this point is interesting that formal theory and research about the possible role of family in the development of anomy has been proposed recently in psychology and psychiatry literature. In fact, development of the systematic paradigm of family function and its effects on its members has not been revealed by the mid twenty century [3].

After the decline of psychopathic theories, an alternative approach which emphasized on the family system (as a single general system) emerged at the end of 1950 and 1960. At these years, the attention focus of clinical experts and theorists went toward human communication dynamics with specific attention to schizophrenia. After that, systemic paradigm and family were proposed as a transformed system by Minchin [4].

\section{Literature Review}

Findings of Minchin's studies [5] [6] [7] indicate that emotional and behavioral problems are due to family structural characteristics and so any change in undesirable structure of family which continues these problems, can be effective in changing patient's symptoms.

[8] indicates that family is a cybernetic system in which each member's behavior is related to each individual's equal system functionally and so their rupture is not so important.

In recent years, this belief has been proposed that family processes are related with creation and maintenance of family members' mental and behavioral disorder. The main point is that family members' behavior is related functionally to the environment that family provides for their nurturing. Almost all schools of thought agree on this belief that peoples' behavior is related to their family envi- 
ronment functionally [9].

[10] has done a study named "examining the performance of schizophrenia families and their non-schizophrenia counterparts" and found that there is a significant difference between general performance of families and their elements (problem solving, communication, roles, affective assistance, affective association and behavior control) in schizophrenic patients and non schizophrenic counterparts.

[10] believes about family training that hygiene training means communicating with people and social groups with the aim of positive health development and eroding disease through influencing and changing people's attitude, beliefs and behavior.

Promoting family members' awareness level, changing their attitude toward mental disorder patients, promoting social adjustment level and self esteem of family members and specially their parents, teaching life skills, promoting family members' temperament and so on, can be effective in controlling and caring chronic mental disorder patients in family [10].

Studies carried on by [11] indicate the role of coherent processes of family interaction on family members' pathology.

Researches indicate that in the family as a systematic, structural and dynamic system, behavior of each member is related to equal systems of each family member functionally and the rupture of this relationships isn't so important [12].

Brogan (1985) considers health promotion and disease prevention parts of general health concept [13].

[14] did a research named "examining the relationship between family performance with mental conditions in peculiar patients" and found that family performance influences mental condition in peculiar patients.

World Health Organization has done a study entitled "family training protocol: a fundamental step towards promoting mental hygiene and family health" and found that family health is important in three period: (1) pre marriage consultations, (2) organizing successful and agreeable marital communications, and (3) child training.

[14] has done a study by the name of "examining the effects of life skills training on self esteem" and found that life skills training can result in more self esteem.

[15] [16] have done a study with the title of "the effects of life skills training on students' mental health" and found that life skills training can result in mental health promotion, anxiety reduction, depression reduction and students' social function promotion.

Family and environmental hygiene is one of the subjects which is taught for parents in family training courses and the significance of this subject in family training courses is because of necessity of providing a familial and social environment conforming to physical and mental hygiene principles for a healthful and constructive life for the parents and their children. This issue is more important in the families which have chronic patients [17].

Just as hygiene is the responsibility of medicine and its duty is very important 
and physical health of the people is related to it, hygiene and mental health of the citizens has gain importance for experts and authorities and they consider training as the main path to mental health promotion [18] [19].

In this study, researchers are going to examine this issue that: Are family training (for example, training skills such as negative temperament, controlling and reducing cognitive errors, gender roles, conflict resolving, financial management and ...) and life skills training (for example, training skills such as creative thinking, critical thinking, decision making skills, problem solving, stress control, anger control and communicative skills) effective in family members' attitude and awareness in caring for chronic mental patients in the family or not? In other words, are these trainings effective in social compatibility level, self esteem, general health promotion and reducing mental disorder in influential family members which have patients with chronic mental problems?

\section{Methodology}

This research is a semi-empirical type of researches which is done with the aim of examining the effects of family trainings and life skills training on the family with chronic mental disorder patients on their taking care of these patients in the family in Mashhad. Statistical population of this research is all the families of male and female chronic mental disorders who have been admitted in round the clock and daily centers and also families of chronic mental disorders in waiting list (nearly 2800 families).

The sample includes 300 families (influential family members). In experiment group, 75 families were selected stratified randomly from families of chronic mental disorders admitted in round the clock and daily centers of Samen, Atef, Ghaem, Hasti, and Toos centers and 75 families are selected systematic randomly from enrolled families in waiting list. This group received one and half hours of family training and life skill training in 12 to 15 sessions. Another 150 families were selected systematic randomly from enrolled families in waiting list as control group. This group received no training. It should be noted that selected subjects were influential family members and mainly family protector, but because of research limitations and other reasons, experiment group reduced to 80 and control group to 110 .

\subsection{Research Instruments}

In general, different dimensions which are examined in this research are measured by five tests and questionnaires: (1) California social adjustment questionnaire, (2) Rosenberg self esteem, (3) general health questionnaire (GHQ), (4) SCL-90-R questionnaire and (5) researcher made questionnaire for measuring families' attitude and awareness about life skills and family trainings (based on Likert attitude test).

\subsection{Data Analysis Methods}

In this research, descriptive statistics indices are used for examining and de- 
scribing demographic characteristics of subjects (in both experiment and control groups) and inferential statistics indices such as t-test in independent groups, K2 test, variance analysis test (F) and Shefe and Toki pursuit test are used for inferential analysis of data. Above analyses were done with SPSS software.

\subsection{Research Results}

According to the first hypothesis: "family and life skills trainings are influential in family members' attitudes towards caring mental disorder patients in the family", for testing this hypothesis in both experiment and control groups, t-test is used in independent group and then in dependant groups in researcher made test (Table 1).

As absolute value of $t$ calculated with degree of freedom of $188(t=0.949)$ is less than $t$ standard $(t=1.980)$, so null hypothesis is confirmed. So we conclude with $95 \%$ confidence that "difference in averages of two control and experiment groups in attitude test toward caring patients in family" is not confirmed.

According to information gathered and because of insignificant differences between averages, we conclude that researcher's claim about "difference in family attitudes toward caring mental disorder patients in family" is not confirmed. In other word, family and life skills trainings do not result in differences in both control and experiment group in respect to caring patients in family. Differences in averages of pre- and post-tests of control and experiment groups in attitude test toward caring chronic mental disorder patients in family is not significant.

For testing second hypothesis of the study "the effect of family and life skills on attitude, awareness and knowledge of family members about life skills" in both control and experiment group, t-test in independent groups and then in dependant groups in researcher made test is used (Table 2).

As $t$ absolute value calculated by degree of freedom of $188(t=5.193)$ is bigger than standard $\mathrm{t}(\mathrm{t}=1.980)$, so null hypothesis is not confirmed. So we conclude with $95 \%$ confidence that "average differences of both control and experiment groups in test of family attitude toward life skills" isn't confirmed.

Table 1. Abstract t-test result in independent groups in order to comparing Means in experimental and control group in attitude of caring mental illness in family.

\begin{tabular}{|c|c|c|c|c|c|c|}
\hline \multirow{2}{*}{$\begin{array}{l}\text { Variables } \\
\text { groups }\end{array}$} & \multirow{2}{*}{ Numbers } & \multirow{2}{*}{ Means } & \multirow{2}{*}{$\begin{array}{l}\text { Standard } \\
\text { deviation }\end{array}$} & \multicolumn{3}{|c|}{ t-test } \\
\hline & & & & $\mathrm{t}$ & $\mathrm{df}$ & $P$ \\
\hline Experimental group & 80 & -0.450 & 8.23 & -0.949 & 188 & 0.344 \\
\hline Control group & 110 & 0.450 & 6.23 & & & \\
\hline
\end{tabular}

Table 2. Abstract t-test result in independent groups in order to comparing Means in experimental and control group in attitude of family to life strategies.

\begin{tabular}{ccccccc}
\hline Variables & Numbers & Means & \multirow{2}{*}{$\begin{array}{c}\text { Standard } \\
\text { groups }\end{array}$} & & \multicolumn{3}{c}{ t-test } \\
\cline { 5 - 7 } & & & deviation & $\mathrm{t}$ & $\mathrm{df}$ & $P$ \\
\hline Experimental group & 80 & -12.19 & 28.55 & -5.193 & 188 & 0.000 \\
Control group & 110 & -1.37 & 25.28 & & & \\
\hline
\end{tabular}


According to information gathered and because of significant differences between averages, we conclude that researcher's claim about "difference in family attitudes toward life skills" is confirmed. In other words, family and life skills training have made differences in both control and experiment's attitude. Average differences in pre- and post-test of experiment group have been significant but not in control group (Table 3).

Examinations related to third hypothesis of research that is " the effect of family and life skills trainings on family members' attitude toward chronic mental disorders in family atmosphere" indicates that as $\mathrm{t}$ absolute value calculated with degree of freedom of $188(t=-2.47)$ is bigger than standard $t(t=-1.980)$, so null hypothesis is not confirmed. So we conclude with $95 \%$ of confidence that "average differences of both control and experimental in attitude test toward chronic mental disorder in family" isn't confirmed.

According to information gathered and because of significant differences between averages, we conclude that researcher's claim about "difference in family attitudes toward chronic mental disorders" is confirmed. Family and life skills training have made significant differences in family members' attitude toward chronic mental disorders. This difference in pre- and post test of experiment group is significant but not in control group.

Examination of fourth hypothesis, that is "effect of family and life skills training on family influential members' social adjustment" in both control and experiment groups is done by California social adjustment test (Table 4).

As $t$ absolute value calculated by degree of freedom of $188(t=16.54)$ is bigger than standard $\mathrm{t}(\mathrm{t}=1.980)$, so null hypothesis is not confirmed. So we conclude with $95 \%$ confidence that "average differences of both control and experiment groups in test of California social adjustment (total scale point)" is confirmed.

According to information gathered and because of significant differences between averages, we conclude that researcher's claim about "difference in the rate of social adjustment (total scale point)" is confirmed and these two groups have

Table 3. Abstract t-test result in independent groups in order to comparing Means in experimental and control group in attitude of family test to mental illness.

\begin{tabular}{cccccccc}
\hline \multirow{2}{*}{$\begin{array}{c}\text { Variables } \\
\text { groups }\end{array}$} & Numbers & Means & $\begin{array}{c}\text { Standard } \\
\text { deviation }\end{array}$ & \multicolumn{3}{c}{ t-test } \\
\cline { 5 - 7 } & & & & $\mathrm{t}$ & $\mathrm{df}$ & $p$ \\
\hline $\begin{array}{c}\text { Experimental group } \\
\text { Control group }\end{array}$ & 80 & -3.959 & 11.72 & -2.47 & 188 & 0.015 \\
\hline
\end{tabular}

Table 4. Abstract t-test result in independent groups in order to comparing Means in experimental and control group in social adjustment test (total score).

\begin{tabular}{cccccccc}
\hline \multirow{2}{*}{$\begin{array}{c}\text { Variables } \\
\text { groups }\end{array}$} & Numbers & Means & $\begin{array}{c}\text { Standard } \\
\text { deviation }\end{array}$ & \multicolumn{3}{c}{$\mathrm{t}$-test } \\
\cline { 5 - 7 } & & & & & $\mathrm{d}$ & $p$ \\
\hline Experimental group & 80 & -28.81 & 11.19 & 16.54 & 188 & 0.000 \\
Control group & 110 & -0.68 & 11.84 & & & \\
\hline
\end{tabular}


significant differences in this respect. In general family and life skills training have significant effects on social adjustment of influential family members (total scale point and all the sub tests of this scale). This difference in pre- and post test of experiment group is significant but not in control group (Table 5).

According to fifth hypothesis of the research, "family and life skills training have effects on family influential members' self esteem." As $t$ absolute value calculated by degree of freedom of $188(t=12.92)$ is bigger than standard $t(t=$ 1.980 ), so null hypothesis is not confirmed. So we conclude with $95 \%$ confidence that "average differences of both control and experiment groups in test of Rosenberg self esteem test" is confirmed.

According to information gathered and because of significant differences between averages, we conclude that researcher's claim about "difference in the rate of social self esteem in both control and experiment groups" is confirmed. This difference in pre-test and post test of Rosenberg self esteem scale is significant in experiment group but not in control group.

Examination of sixth hypothesis, that is "effect of family and life skills training on family influential members' general health" in both control and experiment groups is done by general health test (Table 6).

As $t$ absolute value calculated by degree of freedom of $188(t=11.09)$ is bigger than standard $t(t=1.980)$, so null hypothesis is not confirmed. So we conclude with $95 \%$ confidence that "average differences of both control and experiment groups in test of general health (total scale point)" is confirmed.

According to information gathered and because of significant differences between averages, we conclude that researcher's claim about "difference in the test of general health (total scale point)" is confirmed. Studies indicate that family and life skills training have significant effects on general health of influential family members (total scale point and all the sub tests of this scale). This difference in total scale point of pre- and post test of experiment group is significant but not in control group.

Table 5. Abstract t-test result in independent groups in order to comparing Means in experimental and control group in self esteem test.

\begin{tabular}{|c|c|c|c|c|c|c|}
\hline \multirow{2}{*}{$\begin{array}{l}\text { Variables } \\
\text { groups }\end{array}$} & \multirow{2}{*}{ Numbers } & \multirow{2}{*}{ Means } & \multirow{2}{*}{$\begin{array}{l}\text { Standard } \\
\text { deviation }\end{array}$} & \multicolumn{3}{|c|}{ t-test } \\
\hline & & & & $t$ & df & $p$ \\
\hline Experimental group & 80 & -6.61 & 4.50 & 12.92 & 188 & 0.000 \\
\hline Control group & 110 & 0.78 & 3.39 & & & \\
\hline
\end{tabular}

Table 6. Abstract t-test result in independent groups in order to comparing Means in experimental and control group in mental health test (GHQ).

\begin{tabular}{ccccccc}
\hline \multirow{2}{*}{$\begin{array}{c}\text { Variables } \\
\text { groups }\end{array}$} & Numbers & Means & $\begin{array}{c}\text { Standard } \\
\text { deviation }\end{array}$ & \multicolumn{3}{c}{ t-test } \\
\hline Experimental group & 80 & -29.81 & 5.29 & 11.09 & 188 & 0.000 \\
Control group & 100 & 0.06 & 3.35 & & & \\
\hline
\end{tabular}


According to seventh hypothesis, "family and life skills training have effects on reducing family influential members' mental disorders." This hypothesis is examined in both experiment and control groups by SCl-90-r (Table 7).

As $t$ absolute value calculated by degree of freedom of $188(t=11.015)$ is bigger than standard $\mathrm{t}(\mathrm{t}=1.980)$, so null hypothesis is not confirmed. So we conclude with 95\% confidence that "average differences of both control and experiment groups in test of Epidemiological mental disorders questionnaire (total scale point)" is confirmed.

According to information gathered and because of significant differences between averages, we conclude that researcher's claim about "difference in the test of Epidemiological mental disorders questionnaire (total scale point)" is confirmed. This difference in experiment group with respect to total scale point of Epidemiological mental disorders and its sub test(except for psychopathic sub test) is significant but not in control group.

\section{Discussion}

Nowadays, societies encountered a fast and increasing development, such that we can name present era the age of unpredictable and accelerating transformations. For confronting threats and using possible opportunities for attaining organizational goals, organizations must identify their capacities and potentials and amend their weaknesses and strengthen their positions and in doing so, achieve quality and quantity development of their organization.

Studies indicate that family and life skill training to family members can be very influential in empowering society members and reducing social losses. It seems that traditional educational institutions such as family, school and other cultural institutions have not been successful in creating and developing such functions in family at present. Different factors such as mass media, different social and moral positions, social changes, different expectations and values of children and adolescents and their parents has created a great gap. So it is necessary that some opportunities be provided so that families and children and adolescents learn life skills in addition to reading, writing and mathematics abilities. With respect to above subjects, world health organization has provided a program entitled "life skills training" with the aim of promoting mental hygiene level and preventing social and mental losses [20] [21]. As social and cultural factors determine exact nature of life skill programs, trainings may be different considering educational goal and content in different regions and countries.

Table 7. Abstract t-test result in independent groups in order to comparing Means in experimental and control group in SCL-90-R test.

\begin{tabular}{cccccccc}
\hline \multirow{2}{*}{$\begin{array}{c}\text { Variables } \\
\text { groups }\end{array}$} & Numbers & Means & $\begin{array}{c}\text { Standard } \\
\text { deviation }\end{array}$ & & \multicolumn{3}{c}{ t-test } \\
\cline { 5 - 7 } & & & & & $\mathrm{d}$ & $P$ \\
\hline $\begin{array}{c}\text { Experimental group } \\
\text { Control group }\end{array}$ & 80 & 59.57 & 13.89 & 11.015 & 188 & 0.000 \\
\hline
\end{tabular}


Training process is such that trainees involve in the subject of these skills actively. Training begins from knowledge acquiring and continues until its transformation to an attitude and its emergence as a behavior [22] [23].

\section{Conclusions}

As mentioned in previous discussion, the main assumption is that family is a social system which has different influential mechanisms. Promoting family members' awareness level, changing their attitude toward mental disorders, increasing family members' social adjustment level and their self-esteem specially their parents, promoting life skills, promoting family members' temperament and so on all can be influential in controlling and caring chronic mental disorders [4] [5] [6] [12] [15].

The finding of present research based upon the effect of family and life skills training on family members' attitude towards mental disorder in family is in line with researches of [6] [13] [14].

One of the other findings is that family and life skills training have the significant effect on family members' attitude toward mental disorders in family. These results are different in control and experiment groups and indicate of significant difference of experiment group families' attitude toward mental disorder in family. It seems that family and life skills training influence on family members' attitude toward mental disorders. These results are in line with the results of researches of [11] [12] [15].

Adjustment has a wide spectrum and includes dimensions such as family, peers, and society, and above all are the adjustment. It is believed if one has social adjustment, it won't have the problem in other areas. From the old times, researchers are seeking to know and control the factors which can manipulate this variable and factors such as training methods, peers' attitudes and beliefs, family and educational institutions have been more dominant.

Recently, some of the researchers have focused more on another factor of selfesteem and consider it a very influential factor in creating and controlling adjustment behaviors and believe that those who have the positive judgment and perception about themselves will do less antisocial behavior and exhibit positive behavior more and this belief has been confirmed by many studies.

In general, findings of this research in the area of social adjustment and selfesteem are in line with the findings of many researches cited in second chapter [3] [15] [18] [22].

It can be said one of the reasons that collective methods of family and life skills training in the form of cognitive-behavioral are influential is their educational base. Because in this method, both cognitive and behavioral aspects are emphasized. In this approach, individual's cognition about the problem is changed first and then they are trained in behavioral skills such as problem solving and so on in order to experience behavior and cognition simultaneously.

Meanwhile, for some training influential, more time is needed. Controlling other influential factors such as self esteem and subjects' previous social condi- 
tion, controlling social and economic condition of families, marital style of families, social interaction of subjects with their peers, education patterns of teachers and social system of the families, controlling subjects' intelligent conditions and so on all can be influential in the efficacy of family and life skills trainings.

The findings of this study in the area of mental health and mental disorders are in line with many studies [3] [5] [8] [9] [11].

The findings of present study based upon the role of social support (family and life skill training) in reducing mental disorders and promoting family mental health are confirmed in various areas. Anxiety, stress, physical complaints, interpersonal sensitivities and so on are reported more in families with metal disorder patients. So findings of this study are in line with above mentioned studies.

\section{References}

[1] Campbell, J.D., Trophell, P.D., Lavalle, L.F., Katz, I.M., Heine, S.J. and Lehman, D.R. (2006) Self-Concept Clarity: Measurement, Personality Correlates and Cultural Boundaries. Journal of Personality and Social Psychology, 70, 141-156. https://doi.org/10.1037/0022-3514.70.1.141

[2] Wegner, D.M. (1994) Ironic Processes of Mental Control. Psychological Review, 101, 34-52. https://doi.org/10.1037/0033-295X.101.1.34

[3] Carver, R., Vunger, L. and Derry, D. (2003) Gender Identity and Adjustment in Middle Childhood. Sex Roles, 49, 95-109. https://doi.org/10.1023/A:1024423012063

[4] Elias, M.J. (2007) An Action Research Approach to Evaluation the Impact of a Social Decision-Making and Problem-Solving Curriculum for Preventing Behavior and Academic Dysfunction in Children. Evaluation and Program Planning, 14, $397-$ 407. https://doi.org/10.1016/0149-7189(91)90024-B

[5] Florsheim, P.W. (2003) Family and Cultural Factors in the Psychosocial Adjustment of Chinese Adolescent Immigrants. Northwestern University, Evanston, IL, DAI-B $54 / 07,3851$.

[6] Falsafi Nezhad, M.R. (1993) Examining the Effects of Self Esteem on Students' Behavioral Adjustment-12 - 18 Years Old in Class Environment in Qum City. M.A. Dissertation, Teacher Training University.

[7] Goodstein, L.D. and Lanyon, R.I. (2005) Adjustment Behavior and Personality. Arizona State University, Tempe, AZ.

[8] Moosavi Shooshtari, M. (2006) Examining the Relationship between Family Affective Environment with Personal Social Adjustment and Academic Performance of Third Grade Secondary School in Ahvaz City. M.A. Dissertation, Ahvaz University, Ahvaz.

[9] Noori, R. (2004) Life Skills (Critical and Creative Thinking, Self Awareness and Empathy, Confronting Stress). Tehran Toiloe Danesh Publication.

[10] Pahlavan-Zade, S., et al. (1998) Examining Relationship between Self Esteem Rate and Familial, Personal Characteristics of Female Students in Isfahan. Medical Science, 5, 63-78.

[11] Teri, R. and Rust, J.O. (2002) Self-Esteem and Self-Efficacy of College Students with Disabilities. College Student Journal, 36, 214.

[12] Tozandehjani, H. and Seddighi, K. (2006) Examining the Efficiency Cognitive and Behavioral Self Esteem Training on High School Students Social Adjustment in 
Neishabour City, Academy Research, Research Vice President, in Neishabour Azad University.

[13] WHO (1996) Life Skill Training Program. Translated by Noori, R. and Mohammadkhani, P., Iran's Welfare Organization, Cultural Preventing Vice-Presidency.

[14] WHO (2005) Information Series on School Health. Violence Prevention: An Important Element of a Health-Promoting School. WHO/HQ, Geneva.

[15] Grahum, S. and Cockriel, B. (2004) Indexes to Assess Social and Personal Development and the Impact of College. College Student Journal, 30, 502-515.

[16] Greenberg, G.Y. (2001) The Effect of Relationship Enhancement Program on Marital Communication and Self-Esteem. Journal of Applied Social Sciences, 5, 78-94.

[17] Jahnsen, J.W. and Smith, E.R. (2006) Conceptualizing Social Identity: A New Framework and Evidence for the Impact of Different Dimensions. Personality and Social Psychology Bulletin, 25, 120-135.

[18] Kahn, R.H. (2008) The Effect of a Group Support Intervention Program on Depression, Social Adjustment and Self-Esteem of Adolescents in an Overseas American International School. The Catholic University of America, Washington DC, DAI-B 50/05, 1859.

[19] Katz, J., Joiner Jr., E. and Kwon, P.| (2002)| Membership lin a Devalued Social Group and Emotional Well-Being: Developing a Model of Personal Self-Esteem, Collective Self-Esteem, and Group Socialization. Sex Roles, 47, 419-431. https://doi.org/10.1023/A:1021644225878

[20] Khaiiati, F. (1997) Examining the Rate of Efficiency of Self Esteem Training to Mothers' on Their Children's Self Esteem. M.A. Dissertation, Tehran Teacher Training University, Tehran.

[21] Lassiter, E. (2005) An Assessment of the Relationship between Student Perception of School Effectiveness and Student Achievement and Social Adjustment in Zoned Comprehensive Public High Schools. Morgan State University, Baltimore, MD, DAI-A 55/07, 1767.

[22] Mackie, M.D. and Smith, R.E. (2000) Social Psychology. 2nd Edition, Psychology Press, USA.

[23] McGrath, M.M. and Braunstein, A. (2007) The Prediction of Freshmen Attrition of the Importance of Certain Demographic. Academic Financial and Social Factors. College Student Journal, 31, 396-908.

Submit or recommend next manuscript to SCIRP and we will provide best service for you:

Accepting pre-submission inquiries through Email, Facebook, LinkedIn, Twitter, etc. A wide selection of journals (inclusive of 9 subjects, more than 200 journals)

Providing 24-hour high-quality service

User-friendly online submission system

Fair and swift peer-review system

Efficient typesetting and proofreading procedure

Display of the result of downloads and visits, as well as the number of cited articles

Maximum dissemination of your research work

Submit your manuscript at: http://papersubmission.scirp.org/

Or contact ojmp@scirp.org 